J. H. ZHANG ${ }^{1,2,3}$, M. LI ${ }^{1,2}$, F. HAN ${ }^{1,2}$, and Yu X. SHI ${ }^{1,2}$

\title{
STRESS-INDUCED INCREASES IN THE LEVELS OF CASPASES IN THE PREFRONTAL CORTEX IN A RAT MODEL OF PTSD
}

\begin{abstract}
Received May 21, 2014
We investigated the levels of expression of caspase- 3 and 9 in the medial prefrontal cortex (mPFC) of rats subjected to single prolonged stress (SPS), trying to provide a novel insight into the mechanism of how this cortical region is related to post-traumatic stress disorder (PTSD). Fifty male Wistar rats were divided into the control group and four SPS groups examined at days 1,4,7, and 14 after treatment. Expression of caspase- 3 in SPS groups was significantly greater when compared with the control group $(P<0.05)$ and peaked at day 7 after exposure to SPS. In the control group, the intensity of fluorescence of caspase-9positive cells was low, while that in the SPS groups was significantly higher $(P<0.01)$ and peaked at day 4 after exposure to SPS. After SPS episodes, levels of mRNA of caspase-3 and caspase-9, compared with those in the control group, gradually increased and peaked at days 7 and 4 , respectively $(P<0.01)$. Therefore, changes of expression of caspase- 9 and caspase- 3 may play an important role in the pathogenesis of PTSD.
\end{abstract}

\section{Keywords: caspase-3, caspase-9, medial prefrontal cortex, single prolonged stress,} posttraumatic stress disorder (PTSD).

\section{INTRODUCTION}

Post-traumatic stress disorder (PTSD) is an anxietyrelated disorder that develops after exposure to a lifethreatening traumatic experience. It is characterized by symptoms that often endure for years, including continuous re-experience of the traumatic event, avoidance of stimuli associated with the trauma, numbing of general responsiveness, and increased arousal [1-4]. The pathophysiology of PTSD has been widely studied in neuroscience [5]. However, the mechanism of PTSD is not fully understood until now.

Many lines of evidence from researches on both humans and animals now exist that the amygdala, hippocampus, and medial prefrontal cortex (mPFC) play important roles in PTSD-related symptoms [6]. The amygdala has been documented to play such role in fear, rage, and emotional memory [7, 8]. This cortical zone has direct synaptic connections

\footnotetext{
${ }^{1}$ Department of Histology and Embryology, Basic Medical Sciences College, China Medical University, Shenyang, China.

${ }^{2}$ Institute of Pathology and Pathophysiology, China Medical University, Shenyang 110001, China.

${ }^{3}$ Department of Neurology, North Hospital, Shenyang, China.

Correspondence should be addressed to

Yu X. Shi (e-mail: yuxiushi@126.com)or

F. Han (e-mail: hanfangas@yeah.net).
}

to amygdala and can inhibit amygdalar activity [9]. The function of $\mathrm{mPFC}$ in patients with PTSD undergo negative modifications [10].

In our study, we aimed to explore changes of the caspase 3 and caspase 9 amounts in the $\mathrm{mPFC}$, in order to provide experimental evidence for degeneration of the mPFC in an animal model of PTSD. There are indications that changes in the activities of the above enzymes are important factors influencing the functional state of the $\mathrm{mPFC}$.

The model based on a single prolonged stress (SPS) episode is a good animal model of PTSD related to time-dependent dysregulation of the hypothalamuspituilary-adrenal axis (HPAA). This model has been developed and employed for PTSD research [11-13]. Many lines of evidence have implicated that shifts in the mPFC play an important role in modulating HPAA responses to emotional stress $[14,15]$. Thus, the mPFC deserves special attention in attempts to reveal the mechanism of PTSD.

\section{METHODS}

Animals. One hundred healthy male Wistar rats (7 or 8 weeks at the start of the study, weighing approximately $180 \mathrm{~g}$ ) were supplied for all experiments by the Animal 
Experimental Center, China Medical University, were used. All rats were reared in the experimental animal facility for a week to acclimate to new environment $\left(22 \pm 1{ }^{\circ} \mathrm{C}, 55 \pm 5 \%\right.$ humidity, a 12 -h light/dark schedule, free access to food and water).

Animal Model and Experimental Groups. The SPS model consisted of 2-h-long whole body restraint in an animal holder. This was followed immediately by a 20 -min-long episode of forced swimming (water temperature $25^{\circ} \mathrm{C}$, depth of the aquarium $40 \mathrm{~cm}$ ). The rats were allowed to recuperate for $15 \mathrm{~min}$. Then, they were exposed to inhalation of ether vapors until loss of consciousness. After this, the rats were put back into their home cage and left undisturbed until they were euthanazied for the experiments.

The rats were randomly divided into five groups, the normal control group and four SPS-treated groups (1d, $4 \mathrm{~d}, 7 \mathrm{~d}$, and $14 \mathrm{~d})$. Control rats lived in their individual home cages with no handling and were euthanazied after acclimating to their new environment for a week.

Brain Tissue Preparation and Immunohistochemical Analysis of Caspase 3. Rats of each group were transcardially infused with 200-300 $\mathrm{ml}$ of cold saline through the ascending aorta followed by $300 \mathrm{ml}$ of $4 \%$ cold paraformaldehyde solution. The whole brains were rapidly removed, dissected on ice, and subjected to 6- to 10 -h-long post-fixation in $4 \%$ paraformaldehyde at $4{ }^{\circ} \mathrm{C}$. The brain tissue was cut into $15-\mu \mathrm{m}$-thick slices. After treated with $1 \%$ hydrogen peroxide/methanol, the sections were incubated with $10 \%$ normal goat serum for $30 \mathrm{~min}$ at $37^{\circ} \mathrm{C}$, with antibody I (rabbit polyclonal anti-caspase 3 antibody, Cell Signaling, USA, dilution $1: 300$ ) at $4^{\circ} \mathrm{C}$ overnight, and with antibody II (goat polyclonal anti-rabbit IgG, Boster Biological Technology, China, dilution 1:200) for $1 \mathrm{~h}$ at $37^{\circ} \mathrm{C}$. Then, the sections were incubated with avidin-biotin peroxidase complex (Boster Biological Technology, China, dilution $1: 200$ ) for $1 \mathrm{~h}$ at $37^{\circ} \mathrm{C}$. Immunocomplexes were finally visualized with $0.05 \%$ diaminobenzidine.

An independent investigator obtained images from five slices for each rat, and the results were analysized by an image analyzer. The average number of positive cells from the amygdala in each rat (located according to the atlas [16]) was calculated of three sequential brain slices throughout the area of interest and measured for both left and right hemispheres. Counting of positive cells was performed by an individual blind to the treatment conditions, using the same magnification and a identical color scale setting as a correction for background staining.

Immunofluorescence Analysis of Caspase-9. The sections were treated with $5 \%$ bovine serum albumin (BSA) and $0.3 \%$ Triton X-100 in PBS for $30 \mathrm{~min}$ at room temperature, to block non-specific staining. Endogenous peroxidase was inactivated with $3 \% \mathrm{H}_{2} \mathrm{O}_{2}$ in double-distilled $\mathrm{H}_{2} \mathrm{O}$ for $5 \mathrm{~min}$ also at room temperature. The sections were then incubated with mouse anti-caspase 9 monoclonal antibody (Santa Cruz, USA; 1:300) in 2\% BSA-PBS overnight at $4{ }^{\circ} \mathrm{C}$. After being three times washed with PBS, the sections were incubated with FITC goat anti-mouse IgG (Boster, China; 1:50) for $2 \mathrm{~h}$ at room temperature. To assess nonspecific staining, a few sections in every experiment were incubated in the buffer without primary antibody. Slices were then mounted with glycerin and observed using a fluorescence microscope.

Slides were randomly selected from each group. Five visual fields in the mPFC were randomly selected in each slide $(\times 400)$. The optical density (OD) of caspase 9-immunopositive cells was measured in each field, and the OD average was calculated.

Reverse Transcription-Polymerase Chain Reaction (RT-PCR) to Detect Caspase-3 and Caspase-9. Total mRNA of each group was extracted from the basolateral amygdala according to the Trizol kit instructions (Invitrogen, USA), and $1 \mu \mathrm{g}$ of total RNA was reverse-transcribed into cDNA. The latter was amplified using a RNA PCR kit (AM Ver. 3.0, Takara Bio, Japan). The primers were designed and synthetized by the Shenggong Biotech Company (China) according to the serial number from the Genbank; these data are shown in Table 1. The reaction was started at $94^{\circ} \mathrm{C}$ for 2 min and amplified

T a b l e 1. The sequences of caspase 3 , caspase 9 , and $\beta$-actin

Т а б л и ц я 1. Послідовності нуклеотидів для каспази-3, каспази-9 та $\beta$-актину

\begin{tabular}{l|c|c|c}
\hline Name & Upstream primer & Downstream primer & Product size(bp) \\
\hline Caspase 3 & 5'-ctcggtctggtacactatgtcgatg -3' & 5'-ggttaacccgggtaagaatgtgca-3' & 284bp \\
Caspase 9 & 5'-atggacgaagcggatcggcggctcc -3' & 5'-ctatcctgttctcttggagagtcc-3' & 330bp \\
$\beta$-actin & 5'-atcacccacactgtgcccatc-3' & 5'-acagagtacttgcgctcagga-3' & 542bp \\
\hline
\end{tabular}


of 40 cycles of $30 \mathrm{sec}$ at $94^{\circ} \mathrm{C}, 60 \mathrm{sec}$ at $52^{\circ} \mathrm{C}$ (for caspase-3), or $45 \mathrm{sec}$ at $67^{\circ} \mathrm{C}$ (for caspase-9), $45 \mathrm{sec}$ at $72^{\circ} \mathrm{C}$, and ended with a 7 -min-long extension at $72^{\circ} \mathrm{C}$. $\beta$-actin mRNA used as an internal control was co-amplified with caspase 3- or caspase 9-mRNA. The products were observed after electrophoresis on $1.2 \%$ agarose gel, and the density of each band was analyzed using the Gel Image Analysis System (Tanon 2500R, China). The levels of caspase 3- and caspase 9-mRNA were estimated by calculating the density ratio of caspase $3 \mathrm{mRNA} / \beta$-actin mRNA or caspase 9 mRNA/ $\beta$-actin mRNA.

Statistical Analysis. All data were expressed as means \pm s.d. Intergroups differences were analyzed by one-way analysis of variance (ANOVA) using SPSS 13.0 software. Differences with $P<0.05$ were considered statistically significant.

\section{RESULTS}

Immunohistochemical Analysis of Caspase 3 . As is shown in Fig. 1A-E, caspase 3 is widely distributed throughout the $\mathrm{mPFC}$ region, mainly in the cytoplasm. Labelled structures appeared as buffy particles. The results indicated that expression of caspase (mean integral optical density) 3 in SPS groups was significantly greater compared to that in the control group $(P<0.05)$. this index peaked at day 7 after exposure to SPS (Fig. 1F).

Capase-9 Immunofluorescence. Immunofluorescence staining results of capase- 9 are shown in Fig. 2. The caspase-9 protein was located in the cytoplasm (Fig. 2A-E). In the normal control group, the fluorescence of caspase-9-positive cells was weak, while that in the SPS groups was significantly

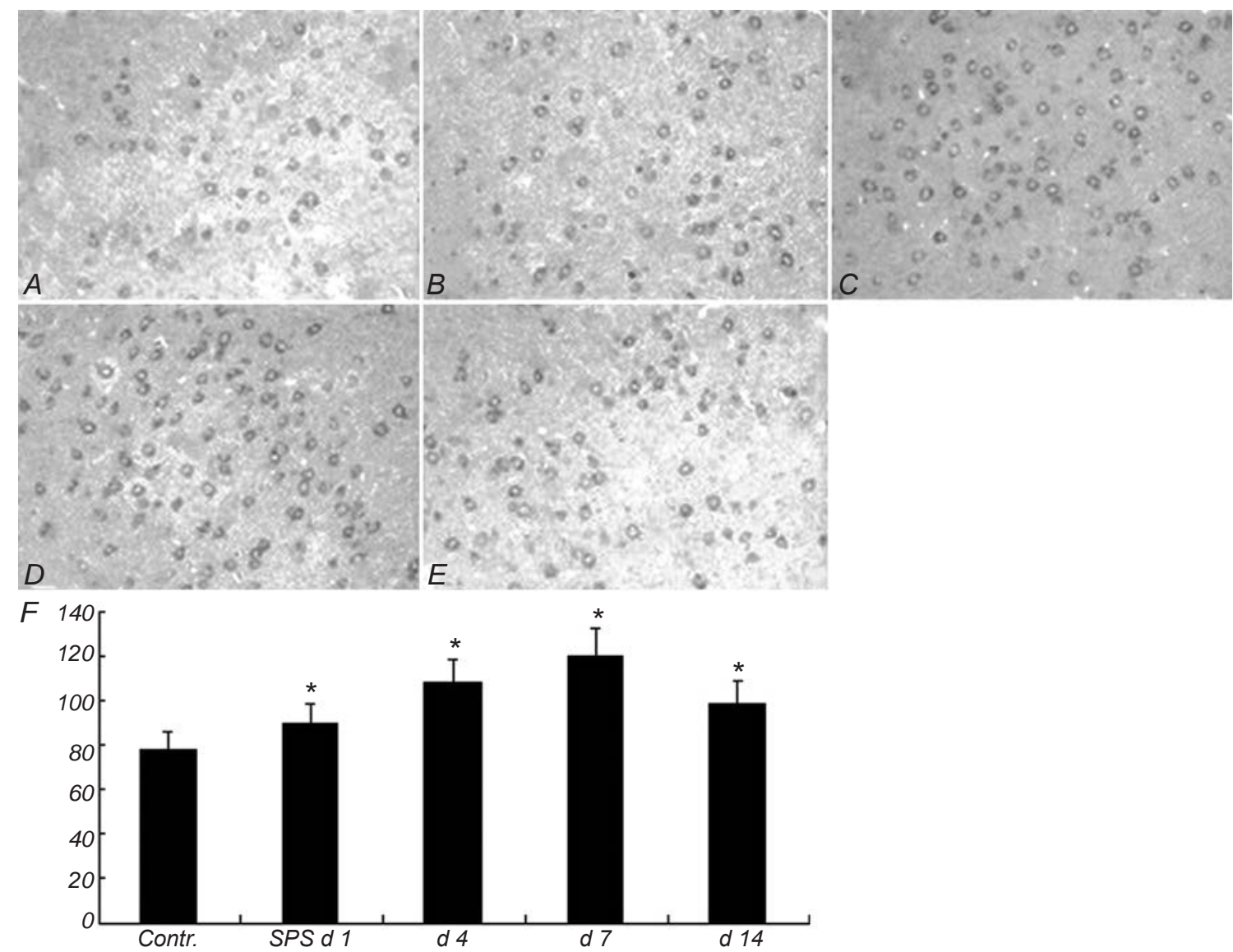

F i g. 1. Expression of caspase 3 in the medial prefrontal cortex (mPFC) of experimental rats. A) In a rat of the control group; B-E), in rats of the groups subjected to single prolonged stress (SPS) at days (d) 1 (B), 4 (C), 7 (D), and 14 (E). ×400. F) Mean integral optical density, arb. units, in slices from animals of the above groups. $* P<0.05$ vs. the control group.

Р и с. 1. Експресія каспази-3 в медіальній префронтальній корі (mPFC) експериментальних щурів. 

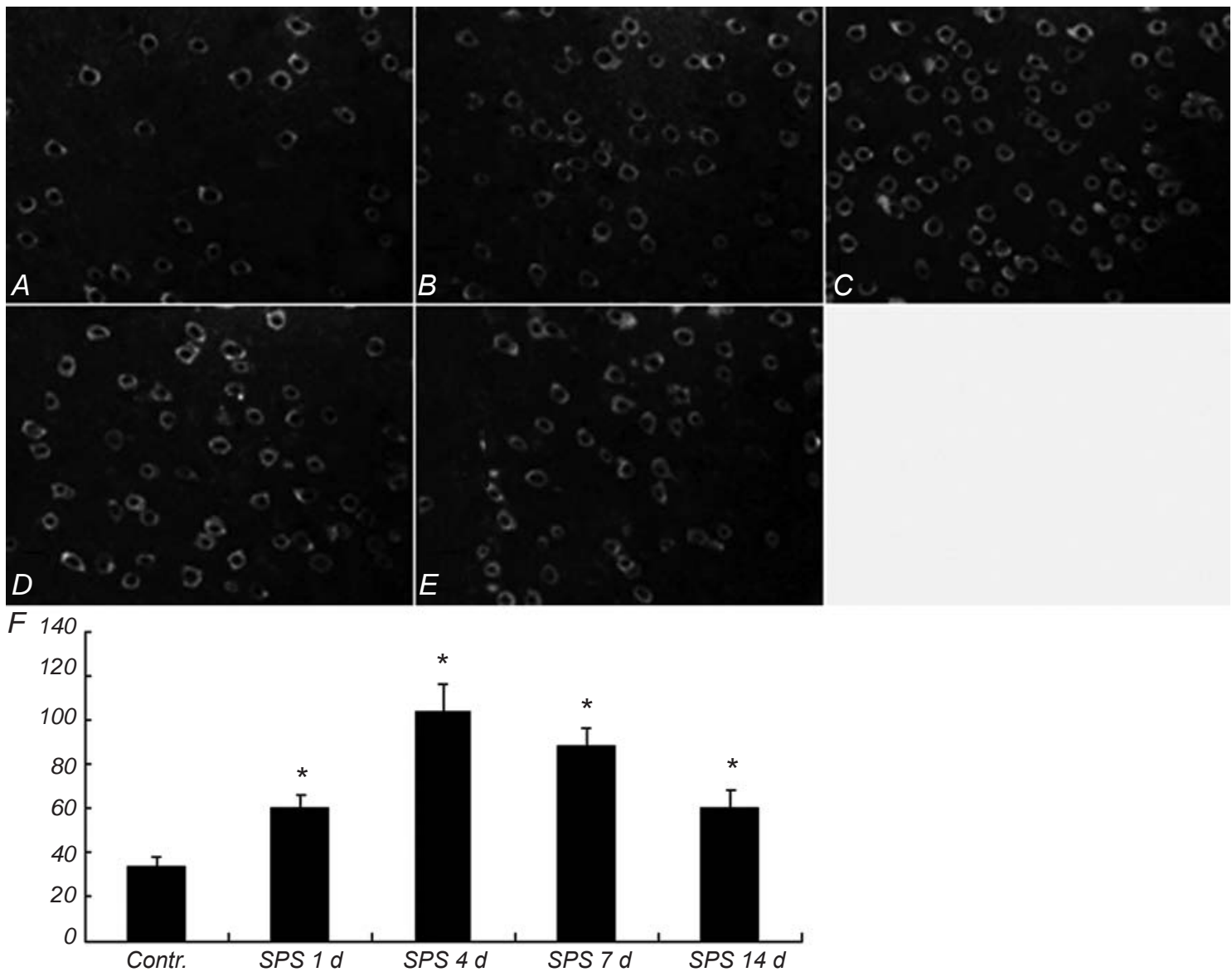

F i g. 2. Expression of caspase 9 in the prefrontal cortex of experimental rats. A-E) Visualization of expression; F) mean fluorescence intensity, arb. units. Designations are similar to those in Fig. 1.

Р и с. 2. Експресія каспази-9 у префронтальній корі експериментальних щурів.

stronger than that in the control $(P<0.01)$. The mean fluorescence intensity in the respective slices peaked at day 4 after exposure to SPS (Fig. 2F).

RT-PCR Results. The levels of caspase- 3 and caspase-9 mRNA were normalized with respect to the $\beta$-actin mRNA level. The representative gel patterns of caspase-3, caspase- 9 , and $\beta$-actin cDNA bands are shown in Fig. 3A. After SPS stimulation, caspase-3 and caspase-9 mRNA levels gradually increased, compared with control group, and peaked at days 7 and 4 after stressing, respectively $(P<0.01)$ (Fig. 3B). This result was consistent with that of immunohistochemical analysis.

\section{DISCUSSION}

PTSD is thought to involve a dysfunction induced by fear-related stimuli. Four major types of typical symptoms of PTSD are the following: re-experiencing, avoidance, numbing, and hyperarousal [1]. Many lines of evidence have implicated a special role of the amygdala; there results were obtained in both animal and human investigations in the processing of threatrelated stimuli, in particular anger and fear. These findings are well-documented $[2,17]$.

Previous studies showed increased activity of the amygdala in patients with PTSD; this was shown by brain imaging. The mPFC can store memories of previous experience, and this plays a key role in the regression on fear conditioning; this cortical area can inhibit amygdalar activity [18]. Studies also showed that declines of mental functions of different degrees in PTSD may be relate to the fact that the mPFC provides descending inhibition of the amygdala inadequately. It was also found that the $\mathrm{mPFC}$ volume in PTSD patients decreases $[19,20]$. So, dysfunction of the $\mathrm{mPFC}$ correlates with reduction of its dimension. 

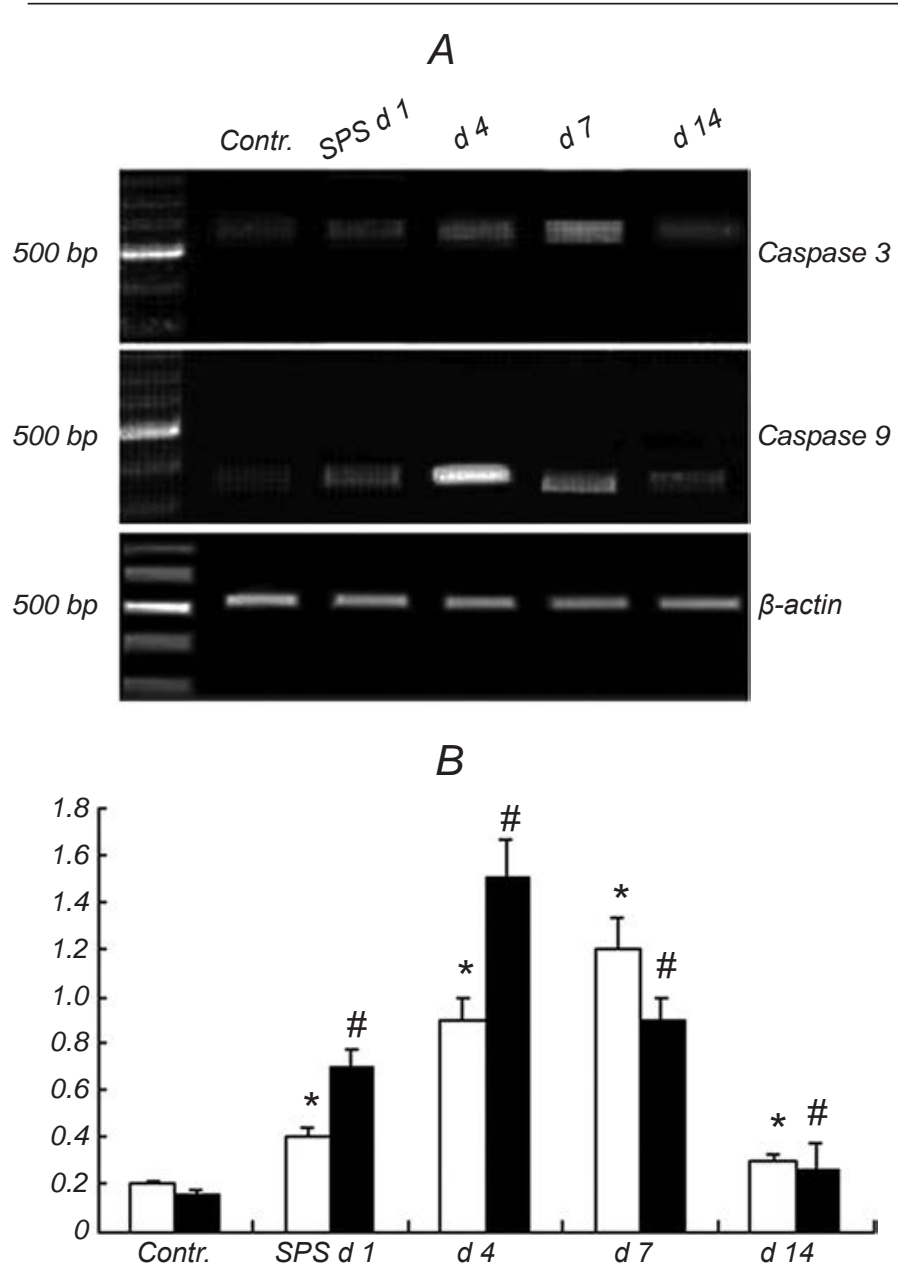

F i g. 3. Results of RT-PCR detection of mRNAs щf caspase 3 and caspase 9 in rats of the experimental groups. A) Representative gel patterns of caspase-3, caspase- 9 , and $\beta$-actin cDNA bands in different experimental groups; B) mean density ratios of caspase $3 \mathrm{mRNA} / \beta$-actin and caspase $9 \mathrm{mRNA} / \beta$-actin (open and filled columns, respectively) in different experimental groups. * and ${ }^{\#} P<0.05$ vs in the control group for caspase- 3 and caspase-9, respectively.

Р и с. 3. Результати детекції мРНК каспази 3 та каспази 9 у щурів експериментальних груп.

To clarify wether apoptosis is responsible for decrease in the volume of the $\mathrm{mPFC}$, we estimated expression of apoptosis-related proteins in the $\mathrm{MPFC}$ neurons of rats with PTSD in our study.

Apoptosis is a genetically programmed and morphologically specific form of cell death that can be triggered by a variety of physiological and pathological stimuli. It is well known that caspases, a family of cysteine-dependent aspartate-directed proteases, play critical roles in initiation and execution of apoptosis by cleaving a large number of proteins, which in turn determine typical morphology of apoptosis [3, 21-23]. In the pathogenesis of apoptosis, activation of caspases is a key link, which eventually lead to degradation of chromosomal DNA and cell disintegration. Caspase-9 is upstream of the start caspases, it mainly provides endogenous activation of the apoptotic pathway to activate the effect of caspase- 3 immediately leading to apoptosis. We found changes of the levels of caspase- 9 and caspase- 3 in the mPFC of rats after treatment with single-prolonged stress. The possible reason of the observed pattern is that such stress results in upregulation of the caspases and leads to dysfunction of the mitochondria, which facilitates the apoptotic process. In our study, detection of expressions of caspase- 3 and caspase-9 in mPFC neurons, using immunohistochemistry, immunofluorescence, and RT-PCR, demonstrated that both these enzymes are upregulated after stress stimulation, and this provides intensification of apoptosis. A limitation of the current study was that we didn't examine relations between the $\mathrm{mPFC}$ and other involved cerebral structures in order to better explore the mechanism of PTSD.

Thus, we demonstrated that the levels of caspase-3 and caspase- 9 significantly increase in the rat $\mathrm{mPFC}$ after the animals were subjected to single prolonged stress. The results suggest that the activity of caspase- 3 and caspase-9 might play an important role in PTSD. At present, the pathogenesis of PTSD is not yet entirely clear. PTSD may cause a series of biochemical abnormalities and dysfunction of the mPFC, which leads to dysfunctions of other related brain structures. It was obvious that the pathogenesis of PTSD needs to be further studied.

Acknowledgments. The authors thank all the staff members in the China Medical University Experiment Center for their technical support on how to improve the quality of the paper. This research has been supported by a grant from the National Natural Science Foundation of China (No. 81171282).

Experiments were performed in accordance with the National Institute of Health Guide for the Care and Use of Laboratory Animals (NIH Publications No. 80-23) revised 1996. All efforts were made to reduce the number of animals used and to minimize animal suffering during the experiment.

The authors, J. H. Zhang, M. Li, F. Han, and Yu X. Shi, confirm that they have no conflict of interest with any organization or person that may be related to this study; there was also no conflict of interest in interrelations between the authors. 
Дж. Х. Жанг $2^{1,2,3}$, М. Лі ${ }^{1,2}$, Ф. Хан ${ }^{1,2}$, Ю. Кс. $\amalg i^{1,2}$

\section{ІНДУКОВАНІ СТРЕСОМ ПІДВИЩЕННЯ РІВНІВ КАСПАЗ У ПРЕФРОНТАЛЬНІЙ КОРІ ЩУРІВ ПРИ МОДЕЛЮВАННІ ПОСТТРАВМАТИЧНОГО СТРЕСО- ВОГО РОЗЛАДУ}

\section{${ }^{1}$ Коледж фундаментальних медичних наук Китайського медичного університету, Шей’ян (Китай).}

${ }^{2}$ Інститут патології та патофізіології Китайського медичного університету, Шен'ян (Китай).

\author{
${ }^{3}$ Північна лікарня, Шен'ян (Китай). \\ Р е $з$ ю м е
}

Ми досліджували рівні експресії каспаз-3 та 9 у медіальній префронтальній корі (mPFC) щурів, підданих поодинокому епізоду тривалого стресу (SPS), намагаючись отримати нові дані щодо механізмів залучення цієї ділянки кори в патогенез посттравматичного стресового розладу (PTSD). 50 самців щурів лінії Вістар були поділені на контрольну групу та SPS-групи, досліджені через одну, чотири, сім та 14 діб після дії SPS. Експресія каспази-3 в групах SPS була вірогідно посиленою порівняно з такою в контрольній групі $(P<0.05)$, досягаючи найвищого рівня через сім діб після впливу SPS. У контрольній групі флуоресценція продуктів виявлення каспази-9 була слабкою, тоді як у групах SPS вона була істотно сильнішою $(P<0.01)$; їі рівень досягав максимуму через чотири доби після дії SPS. Після епізодів SPS рівні мРНК каспаз-3 та 9 поступово збільшувалися, досягаючи пікових значень на сьому та четверту добу відповідно $(P<0.01)$. Отже, зміни експресії каспази-3 та каспази-9 відіграють істотну роль у патогенезі PTSD.

\section{REFERENCES}

1. American Psychiatric Association: Diagnostic and Statistical Manual of Mental Disorders, 4th ed. DSM-IV, Am. Psychiat. Press, Washington (1994).

2. L. Cahill and J. L. McGaugh, "Mechanisms of emotional arousal and lasting declarative memory," Trends Neurosci., 21, No. 7, 294-299 (1998).

3. V. Cryns and J. Yuan, "Proteases to die for," Genes Dev., 12, No. 11, 1551-1570 (1998).

4. H. Cui, H. Sakamoto, S. Higashi, and M. Kawata, "Effects of single-prolonged stress on neurons and their afferent inputs in the amygdale," Neuroscience, 152, No, 3, 703-712 (2008).

5. E. R. de Kloet, "Stress: a neurobiological perspective," Tijdschr. Psychiat., 51, No. 8, 541-550 (2009).

6. E. Vermetten, "Stress, trauma, and post-traumatic stress disorder," Tijdschr. Psychiat., 51, No. 8, 595-602 (2009).

7. J. E. LeDoux, "Emotion: clues from the brain," Annu. Rev.
Psychol., 46, 209-235 (1995).

8. J. L. McGaugh and L. Cahill, "Interaction of neuromodulatory systems in modulating memory storage," Behav. Brain Res., 83, Nos. 1/2, 31-38 (1997).

9. A. J. McDonald, F. Mascagni, and L. Guo, "Projections of the medial and lateral prefrontal cortices to the amygdala: a Phaseolus vulgaris leucoagglutinin study in the rat," Neuroscience, 71, No. 1, 55-75 (1996).

10. L. M. Shin and I. Liberzon, "The Neurocircuitry of fear, stress, and anxiety disorders," Neuropsychopharmacology, 35, No. 1, 169-191 (2009).

11. Y. Iwamoto, S. Morinobu, T. Takahashi, and S. Yamawaki, "Single prolonged stress increases contextual freezing and the expression of glycine transporter 1 and vesicle-associated membrane protein 2 mRNA in the hippocampus of rats," Prog. Neuropsychopharmacol. Biol. Psychiat., 31, No. 3, 642-651 (2007).

12. S. Khan and I. Liberzon, "Topiramate attenuates exaggerated acoustic startle in an animal model of PTSD," Psychopharmacology, 172, No. 2, 225-229 (2004).

13. T. Takahashi, S. Morinobu, Y. Iwamoto, and S. Yamawaki, "Effect of paroxetine on enhanced contextual fear induced by single prolonged stress in rats," Psychopharmacology, 189, No. 2, 165-173 (2006).

14. H. F. Figueiredo, A. Bruestle, B. Bodie, et al., "The medial prefrontal cortex differentially regulates stress-induced $c$-fos expression in the forebrain depending on type of stressor," Eur. J. Neurosci., 18, No. 8, 2357-2364 (2003).

15. J. J. Radley, C. M. Arias, and P. E. Sawchenko, "Regional differentiation of the medial prefrontal cortex in regulating adaptive responses to acute emotional stress," J. Neurosci., 26, No. 50, 12967-12976 (2006).

16. G. Paxinos, C. Watson, and P. C. Emson, "AChE-stained horizontal sections of the rat brain in stereotaxic coordinates," J. Neurosci. Methods, 3, No. 2, 129-149 (1980).

17. J. L. McGauqh, "The amygdala modulates the consolidation of memories of emotionally arousing experience," Annu. Rev. Neurosci., 27, 1-28 (2004).

18. E. A. Phelps, M. R. Delgado, K. I. Nearing, and J. E. LeDoux, "Extinction learning in humans: role of the amygdala and vmPFC," Neuron, 43, No. 6, 897-905 (2004).

19. M. D. De Bellis, M. S. Keshavan, H. Shifflett, et al., "Brain structures in pediatric maltreatment-related posttraumatic stress disorder: a sociodemographically matched study," Biol. Psychiat., 52, No. 11, 1066-1078 (2002).

20. C. Fennema-Notestine, M. B. Stein, C. M. Kennedy, et al., "Brain morphometry in female victims of intimate partner violence with and without posttraumatic stress disorder," Biol. Psychiat., 52, No. 11, 1089-1101 (2002).

21. W. C. Eamshaw, L. M. Martins, and S. H. Kaufmann, "Mammalian caspases: structure, activation, substrates, and functions during apoptosis," Annu. Rev. Biochem., 68, 383424 (1999).

22. D. R. Green and J. C. Reed, "Mitochondria and apoptosis," Science, 281, 1309-1312 (1998).

23. G. Nunez, M. A. Benedict, Y. Hu, and N. Inohara, "Caspases: the proteases of the apoptotic pathway," Oncogene, 17, No. 25, 3237-3245 (1998). 